\title{
Description of Safety Riding Behavior and Knowledge in Adolescents in The South Tangerang Area
}

\author{
${ }^{1}$ Abizar, ${ }^{2}$ Alvian Ramadan, ${ }^{3}$ Ardimas Saputra, ${ }^{4}$ Dewi Wulandari, ${ }^{5}$ Munaya Fauziah \\ Faculty of Public Health, Muhammadiyah University of Jakarta \\ K.H. Ahmad Dahlan St, Cireundeu Ciputat, South Jakarta, 15419 \\ E-mail: ardimassptr@gmail.com
}

\begin{abstract}
Advances in science and technology make the growth rate of vehicles increasing and bring a positive impact on human welfare. The increasing use of vehicles also harms the highway, such as traffic density and vehicles have a very high level of accidents so that motor vehicles become one of the human killers through traffic accidents. Descriptive research method with qualitative approach with phenomenology method. Samples in this study as many as four (4) teenagers consisting of family and Relatives This study wants to explore the phenomenon experienced by teenagers in riding motorcycles. Factors that are the cause of traffic accidents are behavioral factors, knowledge factors, road factors (facilities and infrastructure), and weather factors, where human factors become the highest factors as the cause of traffic accidents. Driving a two-wheeled vehicle needs to be supported by good driving knowledge, gar traffic order can be carried out so that road safety can be realized, in addition to the enforcement of driving standards need to be considered such as the use of helmets and driving papers.
\end{abstract}

Keywords: Safety riding, Knowledge, Behavior 


\section{INTRODUCTION}

Safety Riding is one of the efforts made to minimize the level of danger and to maximize safety in driving to create a condition where we do not harm other motorists and are aware of the possible dangers that can occur around us and an understanding of prevention and unemployment.

Advances in science and technology make the growth rate of vehicles increasing and bring a positive impact on human welfare. The increasing use of vehicles also harms the highway, such as traffic density and vehicles have a significant rate of occurrence of accidents are very high so that motor vehicles become one of the human killers through traffic accidents. (Heryono, Maslina and Zainul, 2020)

World Health Organization (WHO) revealed that $48 \%$ of the victims who died in traffic accidents were people aged 15-44 years. Data from the Central Bureau of Statistics (2015) shows that the most number of motorcycle accidents is 98.88 million units or $81.5 \%$. Indonesia became the third country in Asia with a total of 38,279 traffic accident deaths in 2015. (Hendrawan, 2019)

Who in the Global Status Report on Road Safety (2015) reported that the highest incidence of deaths from motorcycle accidents occurred in Southeast Asian countries and the Asia Pacific countries where the value of each was 34\% (WHO,2015, in (Permatasari, 2018). The DirectorGeneral of Land Transportation revealed that in Indonesia motorcycle accidents in 2013 still ranked the highest at 119,560 incidents. (Permatasari, 2018)

Some factors that cause traffic accidents are human factors (human), vehicle factors, road factors (facilities and infrastructure), and weather factors, where human factors become the highest factors as the cause of traffic accidents (Manurung \&Jefri Rio, 2010). Driving a two-wheeled vehicle needs to be supported by good driving knowledge, gar traffic order can be carried out so that road safety can be realized, in addition to the enforcement of driving standards need to be considered such as the use of helmets and driving papers. (Heryono, Maslina and Zainul, 2020)

Based on initial observations and interviews conducted on teenagers, said to understand about safety riding such as having a driver's license and registration, and memorize about the signs that are on the highway. Aims to know the picture of safety riding in adolescents about the negative-positive impact on remedy knowledge about safety riding and to know which teenagers who have not done safety riding are driving. The benefits of knowing teenagers can know about safe riding and can prevent traffic accidents. . This research was conducted on June 15, 2021 - June 21, 2021. Where the respondent is a teenager who already has a driver's license. Penelitian aims to see teenager's behavior in doing safety riding while driving.

\section{METHODS}

This research uses a qualitative research method with a phenology approach. The data retrieval stemmed from an in-depth interview that was later copied in the form of words on four 
different informant classes. Source triangulation design approach is done on four informants to know the description of safety ridding knowledge on remedy. The data collected in this study are respondents' characteristics, knowledge, attitudes, and behaviors. Variables in this study include free variables such as knowledge about safety riding, attitudes, and behaviors. The bound variable is safety ridding. Informants of this study are teenagers who have had their driver's licenses selected by purposive sampling.

\section{RESULTS AND DISCUSSIONS}

Interview matrix

Identity of the informant

Name : BA

Age/TTL : June 21, 2000

Address: Jalan musyawarah

Occupation: Student

Table 1. Interview Matrix Identitiy of The Informant 1

\begin{tabular}{|c|c|c|c|}
\hline No. & Question & Informant's answer & $\begin{array}{l}\text { Conclusion of the } \\
\text { informant's answer }\end{array}$ \\
\hline 1 & $\begin{array}{l}\text { Please tell us about the first time you drive a } \\
\text { motor vehicle? Since when? (what year) } \\
\text { a. Since when do you have a driver's } \\
\text { license? (what year) }\end{array}$ & $\begin{array}{l}\text { The year } 2017 \text { has a } \\
\text { license fitting ktp so } \\
\text { directly make a license } \\
\text { fitting class } 2 \text { SMK }\end{array}$ & $\begin{array}{l}\text { In } 2017 \text { already have a } \\
\text { driver's license }\end{array}$ \\
\hline 2 & $\begin{array}{l}\text { How did the brothers/sisters feel when they first } \\
\text { got away from motor vehicles? where did the } \\
\text { beginning of the brothers/sisters learn to drive a } \\
\text { motor vehicle? And where did the } \\
\text { brothers/sisters start trying to ride motorcycles? } \\
\text { (highway/village road/alley) }\end{array}$ & $\begin{array}{l}\text { The first time I noticed } \\
\text { this bike ride around the } \\
\text { complex feeling cool so }\end{array}$ & $\begin{array}{l}\text { Have a cool feeling, first } \\
\text { time driving a complex } \\
\text { motor }\end{array}$ \\
\hline 3 & $\begin{array}{l}\text { According to relatives/sisters important not } \\
\text { safety in driving? if it is important why? And if } \\
\text { not why? }\end{array}$ & $\begin{array}{l}\text { There must be many } \\
\text { accidents. }\end{array}$ & $\begin{array}{l}\text { Very important driving } \\
\text { safety }\end{array}$ \\
\hline 4 & $\begin{array}{l}\text { What does the brother/sister think safety in } \\
\text { driving is like? and how do I safety in driving? }\end{array}$ & $\begin{array}{l}\text { We set the speed of the } \\
\text { ride so that not falling }\end{array}$ & $\begin{array}{l}\text { Set the speed when driving } \\
\text { so that it does not crash }\end{array}$ \\
\hline 5 & Name some examples of safety in driving? & $\begin{array}{l}\text { It's like wears a shoe } \\
\text { helmet, gloves like that } \\
\text { anyway }\end{array}$ & Wearing helmets, gloves \\
\hline 6 & $\begin{array}{l}\text { Name some examples of safety in driving that } \\
\text { have you ever done? }\end{array}$ & $\begin{array}{l}\text { Wearing trousers wearing } \\
\text { a rich helmet }\end{array}$ & $\begin{array}{l}\text { Wearing trousers and } \\
\text { wearing a helmet }\end{array}$ \\
\hline 7 & $\begin{array}{l}\text { When doing safety in driving do you feel } \\
\text { difficult or objectionable in doing safety in } \\
\text { driving? }\end{array}$ & $\begin{array}{l}\text { Not at all, that's for } \\
\text { yourself too }\end{array}$ & Don't mind \\
\hline 8 & $\begin{array}{l}\text { According to the brothers/sisters violations in } \\
\text { driving that can threaten the safety of driving is } \\
\text { like what? and mention examples of violations } \\
\text { in driving that could threaten the safety of } \\
\text { driving? }\end{array}$ & $\begin{array}{l}\text { Speeding is not wearing a } \\
\text { helmet }\end{array}$ & $\begin{array}{l}\text { Behave at speed and do not } \\
\text { use a helmet }\end{array}$ \\
\hline 9 & $\begin{array}{l}\text { According to the brothers/sisters, is safety in } \\
\text { driving only done when there are members of } \\
\text { the Police / TNI / DLLAJ on the road? if yes } \\
\text { why? And if not why? }\end{array}$ & $\begin{array}{l}\text { No, anyway because it's } \\
\text { for our safety }\end{array}$ & $\begin{array}{l}\text { No difficulties because for } \\
\text { your safety }\end{array}$ \\
\hline
\end{tabular}




\begin{tabular}{llll}
\hline 10 & $\begin{array}{l}\text { Do brothers/sisters complete vehicle papers } \\
\text { only when there are raids conducted by } \\
\text { members of the Police / TNI / DLLAJ on the } \\
\text { road? if yes why? And if not why? }\end{array}$ & $\begin{array}{l}\text { Always complete rich } \\
\text { stnk sim if necessary } \\
b p k b \text { also }\end{array}$ & $\begin{array}{l}\text { Always complete in-vehicle } \\
\text { mail }\end{array}$ \\
\hline 11 & $\begin{array}{l}\text { In the safety of driving, brothers/sisters must } \\
\text { use helmets, have brothers/sisters not use } \\
\text { helmets when driving a motor vehicle? if yes } \\
\text { why? And if not why? }\end{array}$ & Always use my helmet & Always wear a helmet \\
\hline 12 & $\begin{array}{l}\text { Have you ever committed a violation and } \\
\text { received a ticket sanction? If ever what kind of } \\
\text { violation? And who sanctioned the ticket? }\end{array}$ & $\begin{array}{l}\text { Never then forgot to } \\
\text { bring a driver's license }\end{array}$ & license \\
\hline 13 & $\begin{array}{l}\text { In the law on driving safety, several sanctions } \\
\text { can be given to violators, mention some } \\
\text { sanctions contained in the law of driving } \\
\text { safety? }\end{array}$ & Ouch forget me again & Forget in safety laws \\
\hline 14 & $\begin{array}{l}\text { In driving is it permissible for you to do } \\
\text { anything other than drive? if he why and if not } \\
\text { why? }\end{array}$ & $\begin{array}{l}\text { Engage can have to focus } \\
\text { on driving }\end{array}$ & $\begin{array}{l}\text { No, and should focus on } \\
\text { driving }\end{array}$ \\
\hline 15 & $\begin{array}{l}\text { What is the advice from relatives/sisters to } \\
\text { motorists to always put safety in driving? }\end{array}$ & $\begin{array}{l}\text { We should be ready to } \\
\text { pay before it rains than } \\
\text { later why }\end{array}$ & $\begin{array}{l}\text { Always wear equipment } \\
\text { when driving to avoid } \\
\text { accidents }\end{array}$ \\
\hline 16. & $\begin{array}{l}\text { Do you always pray before driving to avoid } \\
\text { accidents? }\end{array}$ & Sometimes it's not & Yes but rarely. \\
\hline
\end{tabular}

Interview matrix

Identity of the informant

Name: Andhika Gasim

Age/TTL: 21 Years Old

Address: Jl. Birah I No.1b,RT.4/RW,.6, Rw Bar, Kec. Kby. New, South Jakarta, Special Capital

Region of Jakarta 12180

Occupation: freelance employee tokopedia

Table 2. Interview Matrix Identitiy of The Informant 2

\begin{tabular}{|c|c|c|c|}
\hline No. & Question & Informant's answer & $\begin{array}{c}\text { Conclusion of the } \\
\text { informant's answer }\end{array}$ \\
\hline 1 & $\begin{array}{l}\text { Please tell us about the first time you drive a } \\
\text { motor vehicle? Since when? (what year) } \\
\text { b. Since when do you have a driver's } \\
\text { license? (what year) }\end{array}$ & $\begin{array}{l}\text { High School Grade } 2 \text {, has } \\
\text { had a driver's license } \\
\text { since the age of } 18\end{array}$ & $\begin{array}{l}\text { Started driving } 3 \text { junior } \\
\text { high schools and had an 18- } \\
\text { year-old driver's license }\end{array}$ \\
\hline 2 & $\begin{array}{l}\text { How did the brothers/sisters feel when they first } \\
\text { got away from motor vehicles? where did the } \\
\text { beginning of the brothers/sisters learn to drive a } \\
\text { motor vehicle? And where did the } \\
\text { brothers/sisters start trying to ride motorcycles? } \\
\text { (highway/village road/alley) }\end{array}$ & $\begin{array}{l}\text { Thrilled and happy to be } \\
\text { able to ride in one try, } \\
\text { first try in buperta } \\
\text { cibubur }\end{array}$ & $\begin{array}{l}\text { Pleasure in the process of } \\
\text { experimentation, the place } \\
\text { to first try in buperta }\end{array}$ \\
\hline 3 & $\begin{array}{l}\text { According to relatives/sisters important not } \\
\text { safety in driving? if it is important why? And if } \\
\text { not why? }\end{array}$ & $\begin{array}{l}\text { It is very important } \\
\text { because there is a key or } \\
\text { main rule when we drive } \\
\text { the vehicle to be safe to } \\
\text { the destination }\end{array}$ & $\begin{array}{l}\text { It's important to be safe to } \\
\text { get there. }\end{array}$ \\
\hline 4 & $\begin{array}{l}\text { What does the brother/sister think safety in } \\
\text { driving is like? and how do I safety in driving? }\end{array}$ & $\begin{array}{l}\text { Safety in driving that we } \\
\text { respect to fellow road } \\
\text { users also ga only we try }\end{array}$ & $\begin{array}{l}\text { Concerning fellow road } \\
\text { users and always wear the } \\
\text { recommended } \quad \text { driving }\end{array}$ \\
\hline
\end{tabular}




\begin{tabular}{lcc}
\hline No. Question & Informant's answer & $\begin{array}{c}\text { Conclusion of the } \\
\text { informant's answer }\end{array}$ \\
\hline
\end{tabular}

to survive but we do not attributes interfere with others with negligence that we make examples of wearing helmets and not using the path that we should not pass $n$

$5 \quad$ Name some examples of safety in driving? Obey the traffic signs, do not use lanes that are not supposed to be, not reckless

$6 \quad$ Name some examples of safety in driving that have you ever done?

Wearing a helmet, carrying a sim, and not using the busway lane when jammed

7 When doing safety in driving do you feel not Tdak difficult or objectionable in doing safety in driving?

8 According to the brothers/sisters violations in driving that can threaten the safety of driving is like what? and mention examples of violations in driving that could threaten the safety of driving?

9 According to the brothers/sisters, is safety in driving only done when there are members of the Police / TNI / DLLAJ on the road? if yes why? And if not why?

Not wearing a helmet, against the current, and not preparing official driving papers

\section{No, because the safety not}

benchmark when we drive is not based on the police or authorities

10 Do brothers/sisters complete vehicle papers only when there are raids conducted by members of the Police / TNI / DLLAJ on the road? if yes why? And if not why?

11 In the safety of driving, brothers/sisters must use helmets, have brothers/sisters not use helmets when driving a motor vehicle? if yes why? And if not why?

Yes because every time I Yes, bring your driver's travel must bring a license and registration driver's license

Once upon a time but ever

with a short distance from the house, not to the big highway

12 Have you ever committed a violation and Once, because of using received a ticket sanction? If ever what kind of the car lane that at that violation? And who sanctioned the ticket?

time I brought a motorcycle

13 In the law on driving safety, several sanctions can be given to violators, mention some sanctions contained in the law of driving safety?

14 In driving is it permissible for you to do anything other than drive? if he why and if not why?

Not Memorized

Not Memorized

It should not be, because Not because it can harm it can harm the person and others

15 What is the advice from relatives/sisters to Always obey the signs or motorists to always put safety in driving? regulations that exist because it is for yourself not others, as long as obeying the journey will be peaceful and peaceful

16 Do you always pray before driving to avoid Always pray accidents? yourself and others

Always obey the existing rules

Always pray
Obey traffic signs and respect to fellow road users

Wearing a helmet, and not using a busway

Bring a driver's license and do not fight the current 
Interview matrix

Identity of the informant

Name : Inggrid Anggrita

Age/TTL : 24 Years Old

Address: Jalan Albaidho 1 crocodile hole no 52 rt06 rw02 Kel Lubang Buaya Kec Cipayung East

\section{Jakarta}

Occupation: SOE Employee

Table 3. Interview Matrix Identitiy of The Informant 3

\begin{tabular}{|c|c|c|c|}
\hline No. & Question & Informant's answer & $\begin{array}{c}\text { Conclusion of the } \\
\text { informant's answer }\end{array}$ \\
\hline 1 & $\begin{array}{l}\text { Please tell us about the first time you drive a } \\
\text { motor vehicle? Since when? (what year) } \\
\text { c. Since when do you have a driver's } \\
\text { license? (what year) }\end{array}$ & $\begin{array}{l}\text { Junior High School } \\
\text { Grade } 1 \text {, has had a } \\
\text { driver's license since the } \\
\text { age of } 18\end{array}$ & $\begin{array}{l}\text { Started driving } 1 \text { junior } \\
\text { high school and has a } \\
\text { driver's license aged } 18 \\
\text { years }\end{array}$ \\
\hline 2 & $\begin{array}{l}\text { How did the brothers/sisters feel when they first } \\
\text { got away from motor vehicles? where did the } \\
\text { beginning of the brothers/sisters learn to drive a } \\
\text { motor vehicle? And where did the } \\
\text { brothers/sisters start trying to ride motorcycles? } \\
\text { (highway/village road/alley) }\end{array}$ & $\begin{array}{l}\text { Happy because it can and } \\
\text { afraid of fear fall, near } \\
\text { the house, range near the } \\
\text { house }\end{array}$ & $\begin{array}{l}\text { A sense of pleasure and } \\
\text { fear, around the house }\end{array}$ \\
\hline 3 & $\begin{array}{l}\text { According to relatives/sisters important not } \\
\text { safety in driving? if it is important why? And if } \\
\text { not why? }\end{array}$ & $\begin{array}{l}\text { Important, protect } \\
\text { yourself from danger } \\
\text { because we have a heart } \\
\text { Blum, of course, others } \\
\text { heart, so it is better than } \\
\text { yourself who is more } \\
\text { careful }\end{array}$ & $\begin{array}{l}\text { Important and always } \\
\text { careful }\end{array}$ \\
\hline 4 & $\begin{array}{l}\text { What does the brother/sister think safety in } \\
\text { driving is like? and how do I safety in driving? }\end{array}$ & $\begin{array}{l}\text { Safety of driving where } \\
\text { the safety for ourselves is } \\
\text { so with others / other } \\
\text { motorists, by obeying } \\
\text { traffic signs, wearing } \\
\text { motor equipment or } \\
\text { personal protective } \\
\text { equipment }\end{array}$ & $\begin{array}{l}\text { Safety for yourself and } \\
\text { obey traffic as well as use } \\
\text { PPE to drive }\end{array}$ \\
\hline 5 & Name some examples of safety in driving? & $\begin{array}{l}\text { Obey the traffic and do } \\
\text { not speed in the sense of } \\
\text { using the speed standard } \\
\text { only }\end{array}$ & $\begin{array}{l}\text { Use standard speed and } \\
\text { obey the }\end{array}$ \\
\hline 6 & $\begin{array}{l}\text { Name some examples of safety in driving that } \\
\text { have you ever done? }\end{array}$ & $\begin{array}{l}\text { Use PPE to drive and } \\
\text { obey traffic signs }\end{array}$ & $\begin{array}{l}\text { Use PPE to drive and obey } \\
\text { traffic signs }\end{array}$ \\
\hline 7 & $\begin{array}{l}\text { When doing safety in driving do you feel } \\
\text { difficult or objectionable in doing safety in } \\
\text { driving? }\end{array}$ & not & no \\
\hline 8 & $\begin{array}{l}\text { According to the brothers/sisters violations in } \\
\text { driving that can threaten the safety of driving is } \\
\text { like what? and mention examples of violations } \\
\text { in driving that could threaten the safety of } \\
\text { driving? }\end{array}$ & $\begin{array}{l}\text { Do not wear a helmet or } \\
\text { do not use PPE to drive } \\
\text { as the example of the } \\
\text { hate wearing a helmet }\end{array}$ & $\begin{array}{l}\text { Wear PPE drive like } \\
\text { example helmet }\end{array}$ \\
\hline 9 & $\begin{array}{l}\text { According to the brothers/sisters, is safety in } \\
\text { driving only done when there are members of }\end{array}$ & $\begin{array}{l}\text { No, because we don't } \\
\text { know when danger or }\end{array}$ & not \\
\hline
\end{tabular}




\begin{tabular}{|c|c|c|c|}
\hline No. & Question & Informant's answer & $\begin{array}{l}\text { Conclusion of the } \\
\text { informant's answer }\end{array}$ \\
\hline & $\begin{array}{l}\text { the Police / TNI / DLLAJ on the road? if yes } \\
\text { why? And if not why? }\end{array}$ & $\begin{array}{l}\text { other people who are not } \\
\text { careful can harm } \\
\text { ourselves }\end{array}$ & \\
\hline 10 & $\begin{array}{l}\text { Do brothers/sisters complete vehicle papers } \\
\text { only when there are raids conducted by } \\
\text { members of the Police / TNI / DLLAJ on the } \\
\text { road? if yes why? And if not why? }\end{array}$ & $\begin{array}{l}\text { Yes, because every time I } \\
\text { drive must bring a } \\
\text { driver's license and STIM }\end{array}$ & $\begin{array}{l}\text { Yes, bring your driver's } \\
\text { license and registration }\end{array}$ \\
\hline 11 & $\begin{array}{l}\text { In the safety of driving, brothers/sisters must } \\
\text { use helmets, have brothers/sisters not use } \\
\text { helmets when driving a motor vehicle? if yes } \\
\text { why? And if not why? }\end{array}$ & $\begin{array}{l}\text { Never wear just around } \\
\text { the house }\end{array}$ & ever \\
\hline 12 & $\begin{array}{l}\text { Have you ever committed a violation and } \\
\text { received a ticket sanction? If ever what kind of } \\
\text { violation? And who sanctioned the ticket? }\end{array}$ & $\begin{array}{l}\text { Once, the crosser didn't } \\
\text { wear a helmet. Tilang, } \\
\text { Police }\end{array}$ & No hel, tilang, police \\
\hline 13 & $\begin{array}{l}\text { In the law on driving safety, several sanctions } \\
\text { can be given to violators, mention some } \\
\text { sanctions contained in the law of driving } \\
\text { safety? }\end{array}$ & Not Memorized & Not Memorized \\
\hline 14 & $\begin{array}{l}\text { In driving is it permissible for you to do } \\
\text { anything other than drive? if he why and if not } \\
\text { why? }\end{array}$ & $\begin{array}{l}\text { No, Endanger yourself } \\
\text { and other motorists }\end{array}$ & $\begin{array}{l}\text { Not because it can harm } \\
\text { yourself and others }\end{array}$ \\
\hline 15 & $\begin{array}{l}\text { What is the advice from relatives/sisters to } \\
\text { motorists to always put safety in driving? }\end{array}$ & $\begin{array}{l}\text { Never change and always } \\
\text { follow all the rules }\end{array}$ & Always the rules \\
\hline 16 & $\begin{array}{l}\text { Do you always pray before driving to avoid } \\
\text { accidents? }\end{array}$ & Always do & Always do \\
\hline
\end{tabular}

Interview matrix

Identity of the informant

Name: HM

Age/TTL: 20 Years

Address: Jalan KH. Kilin batujaya subdistrict BatuCeper Tangerang City

Occupation: Student

Table 4. Interview Matrix Identitiy of The Informant 4

\begin{tabular}{|c|c|c|c|}
\hline No. & Question & Informant's answer & $\begin{array}{l}\text { Conclusion of the } \\
\text { informant's answer }\end{array}$ \\
\hline 1 & $\begin{array}{l}\text { Please tell us about the first time you drive a } \\
\text { motor vehicle? Since when? (what year) } \\
\text { d. Since when do you have a driver's } \\
\text { license? (what year) }\end{array}$ & $\begin{array}{l}\text { The first time you can } \\
\text { bring a motorcycle is } \\
\text { junior high school, but if } \\
\text { puya sim fit } 17 \text { years }\end{array}$ & $\begin{array}{l}\text { Started driving in junior } \\
\text { high school and has a } \\
\text { driver's license aged } 17 \\
\text { years }\end{array}$ \\
\hline 2 & $\begin{array}{l}\text { How did the brothers/sisters feel when they first } \\
\text { got away from motor vehicles? where did the } \\
\text { beginning of the brothers/sisters learn to drive a } \\
\text { motor vehicle? And where did the } \\
\text { brothers/sisters start trying to ride motorcycles? } \\
\text { (highway/village road/alley) }\end{array}$ & $\begin{array}{l}\text { Happy and feel cool } \\
\text { because you can bring a } \\
\text { motorcycle so, first bring } \\
\text { the bike to the field near } \\
\text { the house }\end{array}$ & $\begin{array}{l}\text { A sense of pleasure in the } \\
\text { trial process, the first place } \\
\text { to try on the field }\end{array}$ \\
\hline 3 & $\begin{array}{l}\text { According to relatives/sisters important not } \\
\text { safety in driving? if it is important why? And if } \\
\text { not why? }\end{array}$ & $\begin{array}{l}\text { It's important because } \\
\text { safety is paramount and } \\
\text { safety is everything }\end{array}$ & Safety is everything \\
\hline 4 & $\begin{array}{l}\text { What does the brother/sister think safety in } \\
\text { driving is like? and how do I safety in driving? }\end{array}$ & $\begin{array}{l}\text { Driving safety is like a } \\
\text { very valuable diamond }\end{array}$ & $\begin{array}{l}\text { Salvation is a treasure of } \\
\text { value }\end{array}$ \\
\hline
\end{tabular}




\begin{tabular}{|c|c|c|c|}
\hline No. & Question & Informant's answer & $\begin{array}{l}\text { Conclusion of the } \\
\text { informant's answer }\end{array}$ \\
\hline & & $\begin{array}{l}\text { for example rich in } \\
\text { obeying the rules of signs } \\
\text { and helmets }\end{array}$ & \\
\hline 5 & Name some examples of safety in driving? & $\begin{array}{l}\text { Wear a helmet, do not } \\
\text { violate the signs, bring } \\
\text { letters, motorcycles do } \\
\text { not in modify-modify, } \\
\text { respect road users }\end{array}$ & $\begin{array}{l}\text { Obey traffic signs and } \\
\text { respect to fellow road users }\end{array}$ \\
\hline 6 & $\begin{array}{l}\text { Name some examples of safety in driving that } \\
\text { have you ever done? }\end{array}$ & $\begin{array}{l}\text { I always wear a helmet, } \\
\text { carry papers, do not } \\
\text { violate signs, respect } \\
\text { each other }\end{array}$ & $\begin{array}{l}\text { Wearing a helmet, not } \\
\text { breaking signs, } \\
\text { respecting road users }\end{array}$ \\
\hline 7 & $\begin{array}{l}\text { When doing safety in driving do you feel } \\
\text { difficult or objectionable in doing safety in } \\
\text { driving? }\end{array}$ & No ordinary difficulties & Tidak \\
\hline 8 & $\begin{array}{l}\text { According to the brothers/sisters violations in } \\
\text { driving that can threaten the safety of driving is } \\
\text { like what? and mention examples of violations } \\
\text { in driving that could threaten the safety of } \\
\text { driving? }\end{array}$ & $\begin{array}{l}\text { The most vulnerable are } \\
\text { not wearing helmets } \\
\text { because they can damage } \\
\text { the head in the event of } \\
\text { an accident }\end{array}$ & Not wearing a helmet \\
\hline 9 & $\begin{array}{l}\text { According to the brothers/sisters, is safety in } \\
\text { driving only done when there are members of } \\
\text { the Police / TNI / DLLAJ on the road? if yes } \\
\text { why? And if not why? }\end{array}$ & $\begin{array}{l}\text { It's not certain we all } \\
\text { have to understand } \\
\text { driving safety }\end{array}$ & not \\
\hline 10 & $\begin{array}{l}\text { Do brothers/sisters complete vehicle papers } \\
\text { only when there are raids conducted by } \\
\text { members of the Police / TNI / DLLAJ on the } \\
\text { road? if yes why? And if not why? }\end{array}$ & $\begin{array}{l}\text { I'm not always ready to } \\
\text { take it anywhere }\end{array}$ & Always carry the letters \\
\hline 11 & $\begin{array}{l}\text { In the safety of driving, brothers/sisters must } \\
\text { use helmets, have brothers/sisters not use } \\
\text { helmets when driving a motor vehicle? if yes } \\
\text { why? And if not why? }\end{array}$ & $\begin{array}{l}\text { If I wear a helmet } \\
\text { continues ya afraid of } \\
\text { damaged hair also } \\
\text { because of dust or } \\
\text { sunlight }\end{array}$ & Always use \\
\hline 12 & $\begin{array}{l}\text { Have you ever committed a violation and } \\
\text { received a ticket sanction? If ever what kind of } \\
\text { violation? And who sanctioned the ticket? }\end{array}$ & $\begin{array}{l}\text { Ever because it has not } \\
\text { any sim at that time } \\
\text { already brought a } \\
\text { motorcycle }\end{array}$ & $\begin{array}{l}\text { Riding a motorcycle does } \\
\text { not carry a driver's license }\end{array}$ \\
\hline 13 & $\begin{array}{l}\text { In the law on driving safety, several sanctions } \\
\text { can be given to violators, mention some } \\
\text { sanctions contained in the law of driving } \\
\text { safety? }\end{array}$ & $\begin{array}{l}\text { Sanctions rich ticket ama } \\
\text { fine it's just the one I } \\
\text { know }\end{array}$ & Memorize only 2 \\
\hline 14 & $\begin{array}{l}\text { In driving is it permissible for you to do } \\
\text { anything other than drive? if he why and if not } \\
\text { why? }\end{array}$ & $\begin{array}{l}\text { It's not okay to drive and } \\
\text { focus on the road. }\end{array}$ & Driving should focus \\
\hline 15 & $\begin{array}{l}\text { What is the advice from relatives/sisters to } \\
\text { motorists to always put safety in driving? }\end{array}$ & $\begin{array}{l}\text { Always obey the signs or } \\
\text { regulations that exist } \\
\text { because it is for yourself } \\
\text { not others, as long as } \\
\text { obeying the journey will } \\
\text { be peaceful and peaceful }\end{array}$ & $\begin{array}{l}\text { Always obey the existing } \\
\text { rules }\end{array}$ \\
\hline 16 & $\begin{array}{l}\text { Do you always pray before driving to avoid } \\
\text { accidents? }\end{array}$ & $\begin{array}{l}\text { I must have prayed } \\
\text { everywhere }\end{array}$ & Always pray \\
\hline
\end{tabular}


Volume I Tahun 2021

November 2021
E-ISSN: 2808-5361

http://e-journal.fkmumj.ac.id/
Proceeding The First Muhammadiyah InternasionalPublic Health and Medicine Conference 
Table 5. Analysis Content

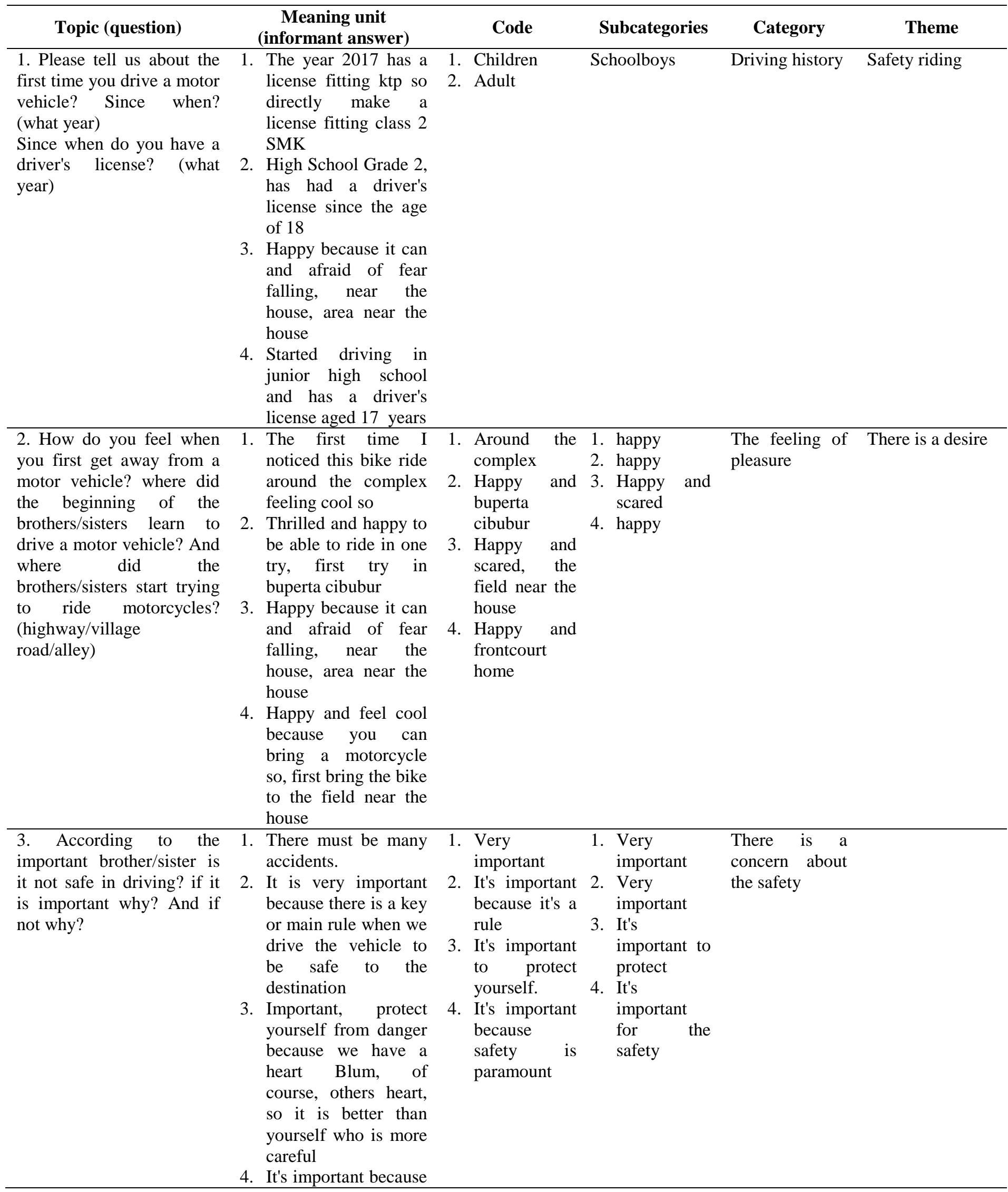




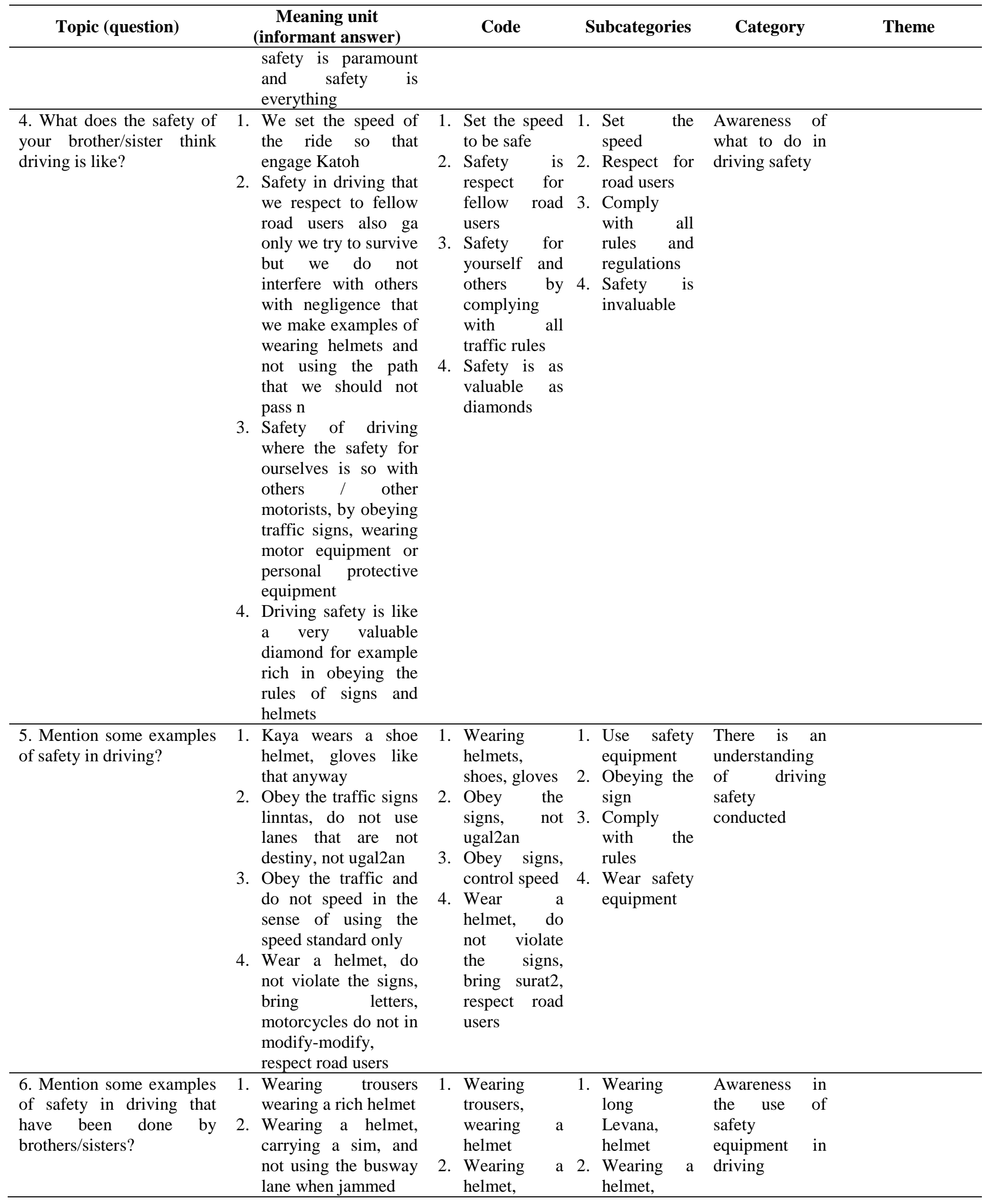




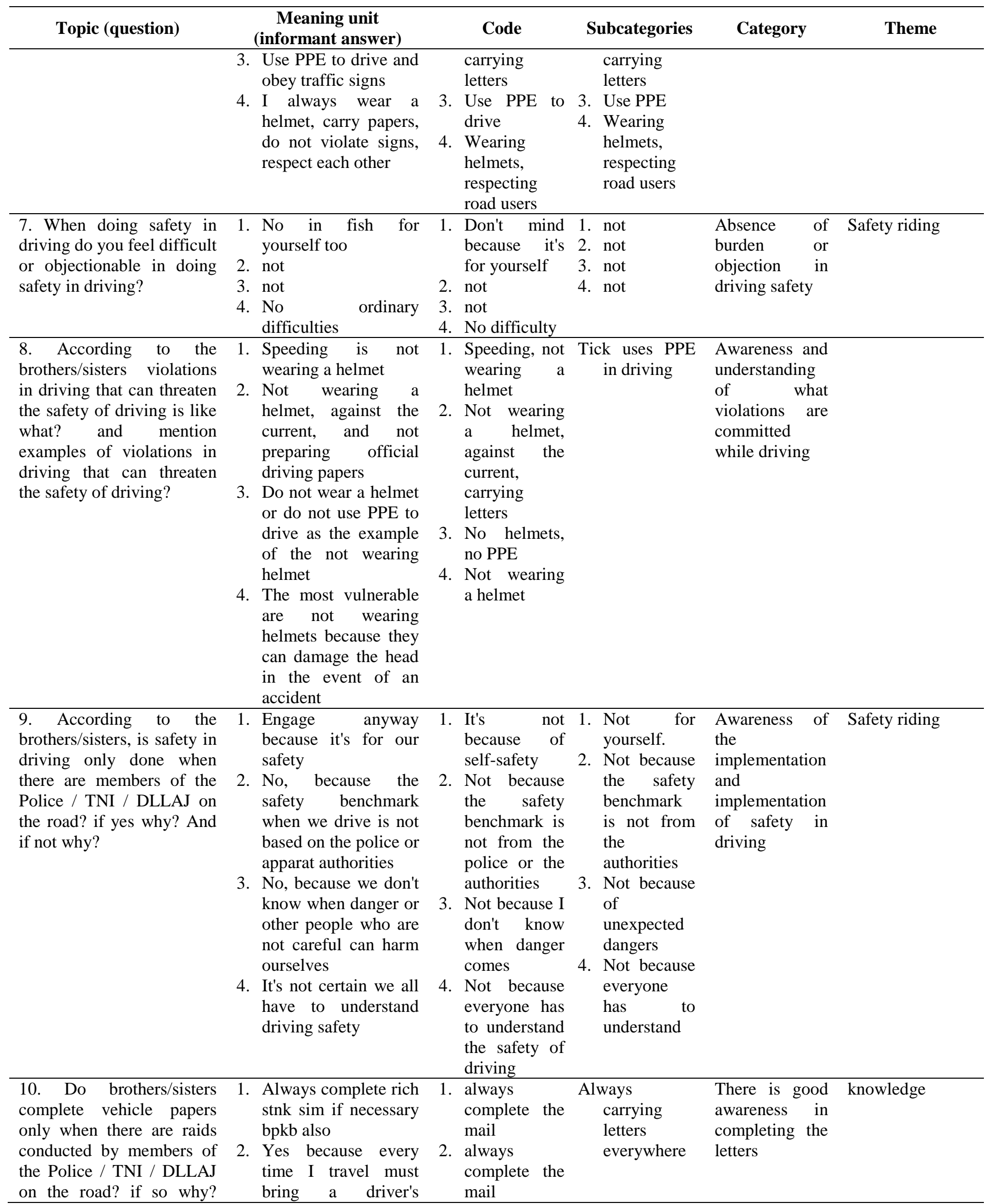




\begin{tabular}{|c|c|c|c|c|c|}
\hline Topic (question) & $\begin{array}{c}\text { Meaning unit } \\
\text { (informant answer) }\end{array}$ & Code & Subcategories & Category & Theme \\
\hline
\end{tabular}

11. In the safety of driving
brothers/sisters must use
helmets, have
brothers/sisters never used
helmets when driving a
motor vehicle? if so why?
And if not why?

if not why?
1. Always use my helmet mah

2. Once upon a time but with a short distance from the house, not to the big highway

3. Never wear just around the house

4. If I wear a helmet continues ya afraid of damaged hair also because of dust or sunlight

12. Have brothers /sisters ever committed violations and received ticket sanctions?
1. Never then forgot to bring a driver's license

2. Once, because of using the car lane that at that time I brought a motorcycle

3. Once, the crosser didn't wear a heel. Tilang, Police

4. Never because I didn't have a driver's license at that time already brought a motorcycle
Always wear 1. Always use a helmet

2. Not use

2. Once because 3. Not use of the 4. Always use proximity

3. Never wear it because it's close

4. Always wear a helmet
There are Safety riding several reasons for the use of helmets or PPE in driving

$\begin{array}{lrlll}\text { 1. Never } & \text { don't } & 1 \text {. ever } & \text { Violations } & \text { knowledge } \\ \text { carry } & \text { a } & \text { 2. ever } & \text { committed by } \\ \text { driver's } & \text { 3. ever } & \text { respondents to } \\ \text { license } & \text { 4. ever } & \text { driving safety }\end{array}$

2. Never been on the wrong track

3. Once because passengers do not wear helmets

4. Never because you don't have a driver's license

13. In the law on driving safety several sanctions can be given to violators,

1. Ouch forget me again

1. forget

2. Not Memorized

2. Not memorized

1. Not memorized

There is a knowledge

3. Not Memorized

3. Not memorized contained in the law of driving safety?

4. Sanctions rich ticket ama fine it's just the one I know

4. Memorize only 2

1. Not memorized problem in the hospital not understand memorized the rules in

3. Memorize driving safety only 2

14. In driving is it 1. Not focus on driving permissible for a 2. It should not be, brother/sister to do because it can harm something other than the person and others driving?
3. No, Endanger yourself and other motorists

4. It's not okay to drive and focus on the road.
1. Must focus 1. Must focus There is an knowledge on driving 2. Can be understanding

2. Not bleh dangerous of the dangers because of 3. Can be of driving if harm dangerous doing other

3. Can be 4. Must focus activities dangerous

4. Should not focus 


\begin{tabular}{|c|c|c|c|c|c|}
\hline Topic (question) & $\begin{array}{c}\text { Meaning unit } \\
\text { (informant answer) }\end{array}$ & Code & Subcategories & Category & Theme \\
\hline $\begin{array}{l}\text { 16. Do you always pray } \\
\text { before driving to avoid } \\
\text { accidents? }\end{array}$ & $\begin{array}{l}\text { 1. Sometimes it's not } \\
\text { 2. Always pray } \\
\text { 3. Always pray } \\
\text { 4. Pray every time you } \\
\text { travel anywhere. }\end{array}$ & $\begin{array}{l}\text { 1. infrequently } \\
\text { 2. always } \\
\text { 3. always } \\
\text { 4. always }\end{array}$ & Always pray & $\begin{array}{l}\text { Respondents' } \\
\text { understanding } \\
\text { of safety and } \\
\text { whatever is } \\
\text { done has been } \\
\text { regulated by } \\
\text { ALLAH SWT } \\
\text { has been very } \\
\text { good }\end{array}$ & $\begin{array}{l}\text { Knowledge and } \\
\text { religion }\end{array}$ \\
\hline
\end{tabular}

Safety Riding behavior in this petition includes several things that greatly affect the safety of driving, including driving using safety equipment such as (helmets, gloves, masks), complete the letters in driving, always pray before driving. The results of the study showed that safety riding behavior conducted by respondents such as using personal protective equipment while driving is always the most important. "Use PPE to drive and obey traffic signs".

A person's knowledge of objects has different intensities or levels. Broadly divided into six levels of knowledge namely know, understand, application, analysis, synthesis, and evaluation. Knowledge plays an important role in a job, especially knowledge about safety riding in motorcyclists. Someone who has more knowledge will tend to be careful in doing something. For example, riders who have more knowledge about safety riding when riding a motorcycle will work more carefully compared to workers who do not know about good safety riding, so it can be concluded that motorcyclists who have good safety riding knowledge will comply with traffic regulations and always apply safe driving behavior both themselves and other road users.

\section{CONCLUSION AND SUGGESTIONS}


Safety Riding is one of the efforts made to minimize the level of danger and to maximize safety in driving to create a condition where we do not endanger other drivers and are aware of possible dangers that can occur around us and an understanding of prevention and mitigation The factors that influence it are behavior. and knowledge.

As obedient citizens we should always follow the rules by the local government because this is a reflection of being nice and diligent citizens, good behavior when driving needs to be done for all teenagers who want to go somewhere and don't forget use full driving outfits like helmet and jacket is a simple thing u must follow, last but not least, a brilliant people is an always follow what things that can make $\mathrm{u}$ a better person not too hard to follow when $\mathrm{u}$ drive, it just $\mathrm{u}$ must be a kind of person who does a transport and do not forget license thing u must bring on your pocket or wallet.

\section{REFERENCES}

Hendrawan, R. (2019) ‘Hubungan Pengetahuan Dan Sikap Terhadap Perilaku Safety Riding Pada Siswa Sma Di Kota Surakarta', Kesehatan Masyarakat, pp. 1-13.

Heryono, D., Maslina and Zainul, L. . (2020) 'Hubungan Tingkat Pengetahuan Terhadap Kepatuhan Safety Ridaing pada Remaja di SMA Negeri 8 Balikpapan', Keselamatan, Kesehatan Kerja dan Lindungan Lingkungan, 6(2), pp. 314-320.

Permatasari, A. (2018) Gambaran Perilaku Keselamatan Berkendara Pada Pelajar SMA Dua Mei

Ciputat Timur. 
Volume I Tahun 2021

November 2021
E-ISSN: 2808-5361

http://e-journal.fkmumj.ac.id/
Proceeding The First Muhammadiyah InternasionalPublic Health and Medicine Conference 